\title{
An Analysis of Rule 11 Plea Bargain Options
}

\author{
Shayna M. Sigman $\dagger$
}

Rule 11 of the Federal Rules of Criminal Procedure permits prosecutors and defendants to enter into several types of plea agreements. It states that in exchange for a plea of guilty or nolo contendere, the prosecutor "will do any of the following:

(A) move for dismissal of other charges; or

(B) make a recommendation, or agree not to oppose the defendant's request, for a particular sentence, with the understanding that such recommendation or request shall not be binding upon the court; or

(C) agree that a specific sentence is the appropriate disposition of the case."

Courts must either accept or reject "type A" charge bargain agreements and "type C" sentence bargain agreements. ${ }^{2}$ If a court rejects one of these agreements, the defendant may withdraw his guilty plea. ${ }^{3}$ However, a "type B" sentence bargain agreement does not bind the court, and "if the court does not accept the recommendation or request the defendant nevertheless has no right to withdraw the plea."

To see the difference between type $\mathrm{B}$ and type $\mathrm{C}$ bargains, compare the following two plea agreements:

1. "Defendant 1" agreed to plead guilty to a drug charge and to cooperate with the government investigation. In exchange, the

$\dagger$ B.A. 1997, Boston University; J.D. Candidate 2000, The University of Chicago.

1 FRCrP 11(e)(1)(A)-(C).

2 See FRCrP 11(e)(2).

3 See FRCrP 11(e)(4).

- FRCrP 11(e)(2). This provision, added as an amendment to Rule 11 in 1979, clarified whether a court's failure to follow the prosecutor's recommendation under $11(\mathrm{e})(1)(B)$ constituted an $11(\mathrm{e})(4)$ rejection of the agreement, which then would trigger a right to withdraw the guilty plea. See FRCrP 11 and Advisory Committee Notes (1979 Amendment). Compare United States $v$ White, 583 F2d 819, 826 (6th Cir 1978) (holding that the defendant could withdraw the guilty plea), with United States $v$ Incrovato, 611 F2d 5, 6-7 (1st Cir 1979) (holding that the defendant could not withdraw the guilty plea); United States $v$ Gaertner, 593 F2d 775, 777 (7th Cir 1979) (same); and United States $v$ Henderson, 565 F2d 1119, 1121-23 (9th Cir 1977) (holding that the trial court was not obligated to offer the defendant the chance to withdraw the plea, but suggesting that judges should do so to "eliminate possible misunderstanding and bitterness"). 
government agreed that the appropriate sentence length should be no more than six years. At sentencing, the government convinced the district court that since Defendant 1 had failed to cooperate, the agreement should be voided. The court then entered the guilty plea and sentenced the defendant to six and one-half years in prison. On appeal, the court overturned the sentence on the ground that the district court either should have accepted the original sentence provision or afforded the defendant an opportunity to withdraw his guilty plea. ${ }^{5}$

2. "Defendant 2" agreed to plead guilty to a drug charge and to cooperate as a witness. The prosecutor agreed to recommend a five-year sentence. The district court entered the guilty plea but then imposed a ten-year sentence. The Court of Appeals affirmed the district court's sentence and found that Defendant 2 had no right to withdraw his guilty plea. ${ }^{6}$

The different type of plea agreement entered into by each defendant explains the discrepancy in how the courts treated the two guilty pleas. Defendant 1 had agreed to an 11(e)(1)(C) plea bargain. ${ }^{7}$ When the district court rejected the agreement, even though the rejection was due to the defendant's failure to cooperate, Defendant 1 had a right to withdraw his guilty plea. On the other hand, Defendant 2's plea agreement involved a nonbinding sentence recommendation under 11(e)(1)(B). The court's departure from the sentence recommendation did not grant Defendant 2 the right to withdraw his guilty plea.

The comparison of Defendants 1 and 2 raises several questions. Why did Defendant 2 not seek a bargain of the type $C$ variety, which would have afforded him the opportunity to withdraw his guilty plea if the court did not accept the recommended sentence? And if defendants like Defendant 2 could not negotiate for a type C plea agreement, why would they ever agree to a type B agreement, given the uncertainty of what sentence the judge would impose? Are type B agreements unfair to defendants who enter into them, even when they rationally choose to do so?

5 This example is based on United States $v$ Fernandez, 960 F2d 771 (9th Cir 1991).

- This example is based loosely on United States $v$ Thibodeaux, 811 F2d 847, 848 (5th $\mathrm{Cir}$ 1987) (holding that the district court's failure to warn the defendant formally that the guilty plea could not be withdrawn was harmless error, when a discussion between the court and the defendant clearly showed that the defendant was aware of this fact).

T See Fernandez, 960 F2d at 772.

- For example, when a robber gives his victim the option "your money or your life," it is clearly rational for the victim to choose to hand over her wallet. Nonetheless, contract law recognizes that this is an unfair deal for the victim because it involves duress and, thus, is unenforceable. See Restatement (Second) of Contracts $\S 176$ \& comment b (ALI 1981). One critique of plea bargaining analogizes the defendant's choice to this gunpoint 
Relying on law and economics insights and principles of contract law, this Comment proposes answers to the above questions. Even if type B agreements can disappoint defendants who do not receive the sentence for which they had hoped, defendants may prefer them, ex ante, to the option of going to trial or even to certain type $\mathrm{C}$ agreements. There are, nonetheless, instances in which both defendants and prosecutors would prefer type $\mathrm{C}$ agreements. Yet, some judges are reluctant to consider type $\mathrm{C}$ agreements, which chills some parties from reaching these agreements. ${ }^{9}$ This Comment argues that judges should not only consider type $\mathrm{C}$ agreements, but also should announce to prosecutors and defendants that the type $\mathrm{C}$ option is welcome in the courtroom. Prosecutors and defendants then would be more likely to reach the agreements that they prefer the most.

Part I of this Comment provides a basic framework for analyzing plea agreements under contract law and through the lens of law and economics. Part II analyzes when rational defendants would accept a type B agreement, why type B agreements are fair

threat. See Kenneth Kipnis, Criminal Justice and the Negotiated Plea, 86 Ethics 93, $97-$ 101 (1976).

- See, for example, United States v Seidman, 483 F Supp 156, 158 (D Wis 1980) ("At the outset, the Court would note that it never will accept a Rule 11(e)(1)(C) type plea agreement. It is this Court's prerogative to determine the type of sentence that should be imposed upon a defendant for the offense of which he or she has been adjudged guilty."); United States $v$ Jackson, 563 F2d 1145, 1147 n 4 (4th Cir 1977) ("Of course, no trial judge is required to accept a "Type C plea agreement."). See also In re Yielding, 599 F2d 251, 253 (8th $\mathrm{Cir}$ 1979) (considering a refusal to hear a type $\mathrm{C}$ agreement as rejection of it under Rule 11(e)(2)); Robert E. Scott and William J. Stuntz, Plea Bargaining as Contract, 101 Yale L J 1909, 1953-54 (1992) (contending that the practice of using type C agreements "is discouraged or prohibited in many jurisdictions"); Frank H. Easterbrook, Criminal Procedure as a Market System, 12 J Legal Stud 289, 321 (1983) ("Although Rule 11 allows a bargain fixing a particular sentence, with the consent of the judge, this option is rarely used."). While the sources noted above describe the rejection of type $\mathrm{C}$ agreements because they restrict judicial discretion in sentencing, courts also may disfavor type $\mathrm{C}$ agreements because when judges reject type $C$ agreements the case goes back onto the trial calendar, which disrupts the docket. See Stephen J. Schulhofer, Due Process in Sentencing, $128 \mathrm{U}$ Pa L Rev 733, 745 n 55 (1980).

As a result, prosecutors and defendants can be reluctant to bargain for type $\mathrm{C}$ agreements. See United States $v$ Andrade-Larrios, 39 F3d 986, 991 (9th Cir 1994) (noting that the defense attorney was reluctant to request a type $C$ agreement and thought it was a very delicate situation"); United States v Pimentel, 932 F2d 1029, 1033 (2d Cir 1991) (noting that the government is reluctant to sentence bargain because courts are unlikely to defer to the sentence recommendations); Anthony V. Nanni, An Overview of Criminal Enforcement by the Antitrust Division, in The Antitrust Division and the FTC Speak on Federal Antitrust Enforcement in the 90's 157, 165-66 (PLI 1990) ("We like to use (c) agreements when both parties have a meeting of the minds as to what the appropriate sentence should be. The use of (c) agreements, however, is somewhat more limited than it otherwise would be because of the reluctance of some judges to accept that type of agreement. Because of the failure of some judges to accept the (c) agreements, we have resorted to one or more of the variations of the (b)-type agreement."). 
despite the defendant's inability to withdraw the guilty plea, and how the availability of the type $\mathrm{C}$ agreement affects the prosecutor's and defendant's decision of whether to enter into a plea agreement. Finally, Part III examines the discretionary role of the judge in plea bargaining and argues that judges can best ensure informed plea agreements that reflect the parties' meeting of the minds by considering type $\mathrm{C}$ plea agreements.

\section{A Basic Model of Plea Bargaining}

\section{A. The Applicability of Contract Law to Plea Bargaining}

Prior to the 1970s, the legitimacy of plea bargaining was in question. Still, guilty pleas accounted for approximately 90 percent of all convictions. ${ }^{10}$ While not all defendants pleading guilty had bargained with prosecutors, many had. Prosecutors and defendants did not make these agreements in open court, but rather "in the shrouded mist of unguided prosecutorial discretion." Judges would inquire whether a defendant had received any promises in exchange for pleading guilty, and the defendant would deny that any promises had been made. ${ }^{12}$ Thus, even if a prosecutor did make a promise to a defendant, it was off the record and, consequently, often unenforceable. ${ }^{13}$

Then, in Santobello v New York, ${ }^{14}$ the Supreme Court recognized that "plea bargaining,' is an essential component of the administration of justice. Properly administered, it is to be en-

\footnotetext{
${ }^{10}$ See Santobello v New York, 404 US 257, 264 nn 1-2 (1971) (Douglas concurring), citing the President's Commission on Law Enforcement and Administration of Justice, Task Force Report: The Courts 9 (1967) (estimating that guilty pleas account for 90 percent of all convictions, and perhaps as much as $\mathbf{9 5}$ percent of misdemeanor convictions); Donald J. Newman, Conviction: The Determination of Guilt or Innocence Without Trial 3 (Little, Brown 1966) ("Roughly 90 per cent of all criminal convictions are by pleas of guilty.").

"Scott v United States, 419 F2d 264, 278 (DC Cir 1969) (holding that trial judges should neither participate in plea bargaining nor entice defendants to plead guilty with promises of a lenient sentence).

${ }^{12}$ See Blackledge $v$ Allison, 431 US 63, 76-79 (1977). For other anecdotal accounts of this practice, see Milton Heumann, Plea Bargaining: The Experiences of Prosecutors, Judges, and Defense Attorneys 35-36 (Chicago 1978), and United States v Maggio, 514 F2d 80, 84 (5th Cir 1975) (referring to "when plea bargaining was an under-the-counter process requiring denial in open court").

${ }^{13}$ There was no settled law on whether plea agreements that were broken by prosecutors were enforceable or not. See Peter Westen and David Westin, $A$ Constitutional Law of Remedies for Broken Plea Bargains, 66 Cal L Rev 471, 473-74 (1978) (suggesting that in a legal regime where most convictions are based on bargained-for compromises, the most important right of the criminally accused may be found not in the law of trial procedure, but in the law of contracts).

" 404 US 257 (1971).
} 
couraged." 15 Thus, the Court treated the plea agreement as any other contract, and held that "when a plea rests in any significant degree on a promise or agreement of the prosecutor ... such promise must be fulfilled."16 The Court vacated the lower court's judgment in the case as a result of the prosecutor's breach of the plea agreement. ${ }^{17}$ Subsequently, Rule 11(e) was amended "to give recognition to the propriety of plea discussions; to bring the existence of a plea agreement out into the open in court; and to provide methods for court acceptance or rejection of a plea agreement."18

Since then, courts have employed principles from contract law to regulate plea bargaining. ${ }^{19}$ For example, courts apply the contract law principle of contra proferentem to interpret ambiguities in the plea agreement against the drafter: the government. ${ }^{20}$ Also, the prosecutor cannot withdraw the offer prior to the guilty plea, if the defendant has relied on it to his detriment. ${ }^{21}$ Courts

${ }^{15}$ Id at 260 . The Supreme Court had recognized implicitly that plea agreements could be mutually beneficial arrangements in Brady $v$ United States, 397 US 742, 751-52 (1970) (holding that a guilty plea encouraged by fear of a death sentence is not per se invalid). However, Santobello was the first case in which the Court explicitly approved of plea bargaining.

${ }^{16}$ Santobello, 404 US at 262.

17 The case was remanded to decide whether the appropriate remedy for the breach would be specific performance of the agreement, before a new judge, or rescission of the agreement-permitting the defendant to withdraw his guilty plea. Id at 263.

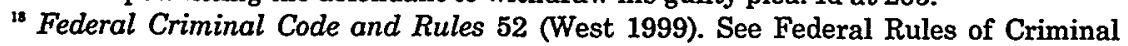
Procedure Amendments Act of 1975, HR Rep No 94-247, 94th Cong, 1st Sess (1975), reprinted in 1975 USCCAN 674, 677-79. See also United States $v$ Bean, 564 F2d 700, 702 (5th Cir 1977) (referring to Rule 11 as "a mechanism for sanctioning discussions between the defendant and the prosecutor and for presenting the agreement in open court for ap. proval by the judge").

${ }^{19}$ United States $v$ Ballis, 28 F3d 1399, 1409 (5th Cir 1994) ("Plea bargain agreements are contractual in nature, and are to be construed accordingly."); United States $v$ Sutton, 794 F2d 1415, 1423 (9th Cir 1986) (holding that plea bargains are "contractual in nature and must be measured by contract law standards"). The analogy to contract law is not perfect. See United States $v$ Hyde, 520 US 670, 677-78 (1997) (treating a type $\mathrm{C}$ agreement as a contract with a condition subsequent-that of judicial approval); United States $v$ Barron, 172 F3d 1153, 1158 (9th Cir 1999) (recognizing that sometimes "the interests at stake and the judicial context . . . require that something more than contract law be applied"); United States $v$ Ingram, 979 F2d 1179, 1184 (7th Cir 1992) (stating that plea bargains are "unique contracts and the ordinary contract principles are supplemented with a concern that the bargaining process not violate the defendant's rights to fundamental fairness under the Due Process clause").

${ }^{2}$ See United States $v$ Hawley, 93 F3d 682, 690 (10th Cir 1996), citing approvingly United States $v$ Massey, 997 F2d 823, 824-25 (10th Cir 1993) ("I]f any ambiguities are present they will be resolved against the drafter, in this case the government."); United States $v$ Harvey, 791 F2d 294, 303 (4th Cir 1986).

21 Compare Mabry $v$ Johnson, 467 US 504, 509-10 (1984) (holding that since "[r]espondent's plea was in no sense induced by the prosecutor's withdrawn offer," the plea was valid), with United States $v$ Savage, 978 F2d 1136, 1138 (9th Cir 1992) ("D]etrimental reliance on a prosecutorial promise in plea bargaining could make a plea 
also place constitutional requirements, based on the Due Process Clause, on the plea bargaining process. ${ }^{22}$ Often, the constitutional requirements and the general principles of contract law coincide. For example, due process requires that plea agreements must be entered into voluntarily-just like any other contract, they cannot be a product of threats or misrepresentation. ${ }^{23}$ Due process also requires that plea agreements be made intelligently. This is analogous to the contract doctrine of mistake, in that the defendant must be aware of the nature of the charge against him and "the actual value of any commitments made to him." ${ }^{24}$ In summation, courts view plea agreements as contracts and use contractual principles to the extent it is constitutionally permissible.

\section{B. The Law and Economics of Plea Bargaining}

Since courts treat plea agreements like contracts, legal scholars have analyzed prosecutors and defendants as market participants attempting to attain the best plea agreement. ${ }^{25}$ For the defendant, this means obtaining the most lenient punishment possible, at the lowest monetary, opportunity, and reputational cost. The defendant will calculate the expected cost of going to trial by multiplying the expected sentence from a trial conviction by the likelihood of conviction, and adding to this product the time, money, and reputation costs of a criminal trial. ${ }^{26}$ Factors that affect the likelihood of conviction are the strength of the evidence ${ }^{27}$ and the balance of resources available to each party for

\footnotetext{
agreement binding.").

${ }^{27}$ See Westen and Westin, A Constitutional Law of Remedies, 66 Cal L Rev at 528-38 (cited in note 13).

${ }^{23}$ See Brady, 397 US at 750 ("[O]f course, the agents of the state may not produce a plea by actual or threatened harm or by mental coercion overbearing the will of the defendant."); Restatement (Second) of Contracts $§ \S 159-77$ (discussing contracts that are unenforceable because they are a product of threats, misrepresentation, coercion, or fraud).

${ }^{24}$ See Brady, 397 US at 755, citing Shelton $v$ United States, 246 F2d 571, $572 \mathrm{n} 2$ (5th Cir 1957), revd on confession of error on other grounds, 356 US 26 (1958). See also Restatement (Second) of Contracts $\S \S 151-53$ (discussing contracts that are unenforceable due to a mistake in a "basic assumption").

${ }^{2}$ See William M. Landes, An Economic Analysis of the Courts, $14 \mathrm{~J} \mathrm{~L} \&$ Econ 61, 66 69 (1971); Edward A. Ruttenberg, Plea Bargaining Analytically: The Nash Solution to the Landes Model, 7 Am J Crim L 323 (1979); Easterbrook, 12 J Legal Stud at 308-22 (cited in note 9); Richard P. Adelstein, The Negotiated Guilty Plea: An Economic and Empirical Analysis 103-76 (Garland 1984); Jennifer F. Reinguam, Plea Bargaining and Prosecutorial Discretion, 78 Am Econ Rev 713 (1988). For a critique of conceptualizing criminal procedure as a market, see Stephen J. Schulhofer, Criminal Justice Discretion as a Regulatory System, 17 J Legal Stud 43 (1988).

${ }^{23}$ See Landes, $14 \mathrm{~J} \mathrm{~L} \&$ Econ at $65-71$ (cited in note 25 ).

${ }^{27}$ While actual innocence or guilt is represented in the calculus only through the inadequate proxy of strength of the evidence, it also may affect the way the defendant views the strength of the evidence or the cost of pleading guilty. For example, an innocent de-
} 
trying the case. ${ }^{28}$ Based on his attitude toward risk, a defendant then may discount or magnify his expected cost of going to trial. ${ }^{29}$

The prosecutor, on the other hand, wants to maximize some combination of the number of convictions and sentence length per conviction. ${ }^{30}$ She also examines the likelihood of conviction from a trial and the expected sentence following conviction. ${ }^{31}$ Her attitude toward risk is a factor too. The prosecutor is far better informed than the defendant about her risk preference and resource constraints-that is, how much time can be spent on this one case compared to others. While the prosecutor faces a similar lack of information as to the defendant's attitude towards risk, the defendant does not enjoy the same informational advantage as to his resources, which are more likely to be visible to the prosecutor. The asymmetry in information can strengthen the prosecutor's bargaining position. ${ }^{32}$

Based on these factors, each party identifies a range of sentences that would be preferable to trial. When the acceptable ranges overlap, the prosecutor and defendant likely will agree upon some point within the overlap for a plea agreement. Determining where this point would fall is complicated. There is no reason to assume that the prosecutor necessarily has the superior bargaining position. The parties are in a bilateral monopolythat is, while the defendant cannot seek out another party to receive a better deal, the prosecutor also must negotiate in each case with that particular defendant. ${ }^{33}$ Therefore, the strength of each case, the resource constraints, the attitudes toward risk, knowledge of the other's acceptable bargaining range, and sheer

fendant may feel that new exculpatory evidence will be uncovered prior to trial or he may have a particular aversion to pleading guilty because it would be dishonest. See Schulhofer, $17 \mathrm{~J}$ Legal Stud at $80 \mathrm{n} 97$ (cited in note 25); Landes, $14 \mathrm{~J} \mathrm{~L} \&$ Econ at 69 (cited in note 25).

${ }^{2}$ Landes, $14 \mathrm{~J} \mathrm{~L} \&$ Econ at 61 (cited in note 25 ).

${ }^{2}$ Id at 67-71.

${ }^{\infty}$ A prosecutor will not merely try to get as many convictions as possible. For example, the prosecutor would not drop a murder charge in order to obtain a guilty plea to a traffic violation, even though it would increase the number of convictions while conserving resources. See id at 63. Likewise, the fact that prosecutors engage in plea bargaining indicates that maximizing the sentence for each defendant's conviction is not their only concern; rather prosecutors maximize the sentences of all defendants in the aggregate.

${ }^{31}$ See id at 63-65. This calculus obtains the socially optimal level of punishment "if expected sentences are regarded as the prices the community charges for various offenses." Id at 63. This assumes that there is equal deterrence from punishments, whether they result from a trial conviction or a guilty plea.

${ }^{32}$ See Avery Katz, When Should an Offer Stick? The Economics of Promissory Estoppel in Preliminary Negotiations, 105 Yale L J 1249, 1298 (1996) ("Tnformational asymmetries also affect the parties' relative bargaining power" in bilateral monopoly cases.).

${ }^{3}$ See Easterbrook, $12 \mathrm{~J}$ Legal Stud at 311 (cited in note 9). 
negotiation skill will dictate which party has the upper hand in any given plea bargain negotiation..$^{34}$

\section{AN Evaluation OF 11(E)(1)(B) AND 11(E)(1)(C) AGREEMENTS}

\section{A. The Efficiency of Type B Plea Agreements}

If the prosecutor's sentence recommendation is not binding on the court, why would a defendant enter into a type B plea agreement? This Part argues that, ex ante, the type B plea agreement has significant value to many defendants because they might be able to negotiate for lower recommended sentences if they are willing to accept the risk that judges might impose harsher sentences than the agreed upon recommendations.

First, judges usually follow the nonbinding recommendation in type B agreements. ${ }^{35}$ Also, judges are aware that plea bargaining participants, such as prosecutors and criminal defense attorneys, are repeat players. If the courts generally do not accept prosecutors' sentence recommendations, it will hamper the parties' ability to reach agreements in future cases. ${ }^{36} \mathrm{~A}$ rational defendant who knows that judges will not listen to or give weight to a prosecutor's sentence recommendation will not agree to a type $\mathrm{B}$ deal. ${ }^{37}$

Nevertheless, a defendant calculating whether to accept a type $B$ plea agreement must factor a risk premium into the cost of pleading guilty. This premium represents the product of the probability that the court will depart from the sentence recommendation and the expected sentence length of such a departure.

\footnotetext{
${ }^{34}$ See Ruttenburg, 7 Am J Crim L at 337-44 (cited in note 25) (arguing that defendants often receive more favorable plea agreements because they are acting through an agent or are acting irrationally). The prosecutor is less able to receive concessions from the defendant, because he is negotiating with the defense attorney, not the defendant. Furthermore, irrational actors sometimes receive better deals than rational ones. See Katz, 105 Yale I J at 1298 (cited in note 32) ("Parties who can establish a credible reputation for stubbornness, spite or even irrationality will increase their bargaining power.").

${ }^{35}$ See Heumann, Plea Bargaining at $\mathbf{1 5 0 - 5 2}$ (cited in note 12) (noting that judges accept most recommendations because they agree with the outcome); Albert W. Alschuler, The Trial Judge's Role in Plea Bargaining, Part I, 76 Colum L Rev 1059, 1066 (1976) (providing anecdotal evidence that judges follow the sentence recommendations).

${ }^{36}$ See United States $v$ Gordon, 61 F3d 263, 267 (4th Cir 1995) ("I]n order to preserve the effectiveness of the plea bargaining system, courts usually will adopt most or all of the recommendations in a nonbinding plea agreement."); Alschuler, 76 Colum L Rev at 106566 (cited in note 35 ) ("[J]udges almost automatically ratify prosecutorial charge reductions and sentence recommendations."); Schulhofer, $128 \mathrm{U} \mathrm{Pa} \mathrm{L} \mathrm{Rev} \mathrm{at} 745$ (cited in note 9).

${ }^{37}$ And if the defendant does not know that the judge will not give any weight to the recommendation, it is the court's responsibility to inform him of it. See United States $v$ Maggio, 514 F2d 80, 89 (5th Cir 1975) (noting that a court that never accepts sentence recommendations should inform the defendant of this).
} 
In addition, defendants must adjust the cost of this premium based on their attitude toward risk.

To illustrate this, ${ }^{38}$ consider again the example of Defendant 2 , discussed at the outset of this Comment. Defendant 2 was facing a trial for a drug charge. Imagine that the charge carried a minimum sentence of five years and a maximum sentence of fifteen. Defendant 2 also knew that there was a 60 percent chance that the jury would convict him.

If the average sentence length of someone convicted at trial for this charge were ten years, the cost to Defendant 2, ex ante, would be an expected sentence of six years (the product of the ten-year average sentence and the 60 percent probability of conviction), plus some length equivalent to the financial, opportunity, and reputational costs of going to trial. ${ }^{39}$ Defendant 2 would accept a prosecutor's offer to plead guilty for a sentence anywhere from zero to six years if the prosecutor could guarantee the sentence received.

A nonbinding type B plea agreement would alter Defendant 2's range of acceptable recommendations. Defendant 2 would need to determine the likelihood of judicial departure from the sentence recommendation and the expected sentence resulting from such a departure. Although the prosecutor bears part of the burden of the risk of judicial departure, since judges can depart downward from the nonbinding recommendation, ${ }^{40}$ it is essentially the defendant who bears this burden since upward departure from a sentence recommendation is far more common. The

3 The analysis in this Part relies on the following model:
$\mathrm{P}_{T}=$ Defendant's probability of conviction at trial;
$\mathrm{S}_{\mathrm{T}}=$ Average sentence length from a conviction at trial;
$\mathrm{C}_{\mathrm{T}}=$ Sentence length equivalent to cost to the defendant of the trial;
$\mathrm{S}_{\mathrm{C}}=$ Sentence recommended in a type $C$ agreement;
$\mathrm{S}_{\mathrm{B}}=$ Sentence recommended in a type $\mathrm{B}$ agreement;
$\mathrm{S}_{\mathrm{J}}=$ Sentence given by the judge after a guilty plea (assuming $\mathrm{S}_{\mathrm{J}}>\mathrm{S}_{\mathrm{B}}$ and $\left.\mathrm{S}_{\mathrm{J}}<\mathrm{S}_{\mathrm{T}}\right) ;$
$\mathrm{P}_{\mathrm{D}}=$ Probability that judge departs from the type $\mathrm{B}$ recommendation $\left(\mathrm{P}_{\mathrm{D}}=\mathrm{f}\left[\mathrm{S}_{\mathrm{J}}-\mathrm{S}_{\mathrm{B}}\right]\right) ;$
$\mathrm{S}_{\mathrm{E}}=$ Expected sentence from a type $\mathrm{B}$ plea agreement $\left(\mathrm{S}_{\mathrm{E}}=\mathrm{S}_{\mathrm{B}}\left[1-\mathrm{P}_{\mathrm{D}}\right]+\left(\mathrm{S}_{J}\right)\left(\mathrm{P}_{\mathrm{D}}\right)\right)$.
A defendant will plea bargain if $\mathrm{S}_{\mathrm{E}}$ is greater than $\left(\mathrm{P}_{\mathrm{T}}\right)\left(\mathrm{S}_{\mathrm{T}}\right)+\mathrm{C}_{\mathrm{T}}$. Since $\mathrm{S}_{\mathrm{J}}>\mathrm{S}_{\mathrm{B}}, \mathrm{S}_{\mathrm{E}}>\mathrm{S}_{\mathrm{B}}$ Type $C$ and type $B$ agreements are equivalent to defendants when $S_{E}=S c$ and thus when $\mathrm{S}_{\mathrm{c}}>\mathrm{S}_{\mathrm{B}}$.

${ }^{30}$ This figure is nearly zero for someone who is indigent, unemployed, and a repeat offender. But it is likely to be higher if the defendant is, for example, a doctor who has unlawfully dispensed drugs, particularly due to reputational harms. To simplify the following analysis, assume that this figure is zero and that Defendant 2 is risk neutral.

* While judges can depart downward under $11(\mathrm{e})(1)(\mathrm{B})$, they may not have the same flexibility to depart from 11(e)(1)(C) plea agreements. See United States $v$ Semler, 883 F2d 832, 833-34 (9th Cir 1989) (holding that Rule 11(e)(3) forbids a lenient departure, even based on Rule $35(b)$, which permits courts to correct illegal sentences, when the sentence was agreed to under an $11(\mathrm{e})(1)(\mathrm{C})$ plea agreement). 
average departure is upwards, because most plea agreements recommend sentences that are closer to the sentencing guideline minimum. ${ }^{41}$ Judges give lower sentences to defendants who plead guilty than those who are found guilty at trial. ${ }^{42}$ Accordingly, on average, even a judge who departs from a sentence recommendation would not impose a greater sentence than the average sentence from a trial conviction.

Assuming that the average judicial departure would impose a sentence of eight years, and the likelihood of departure is 20 percent, Defendant 2's expected punishment cost from entering a type B plea agreement, where the prosecutor recommends a sixyear sentence, would not be six years; rather the expected cost would be six years multiplied by 80 percent plus eight years multiplied by 20 percent, or approximately six years and five months. This is above Defendant 2's acceptable plea bargaining range, since his ex ante sentence from trial is six years. To achieve the equivalent of a guaranteed six-year sentence, the prosecutor would need to recommend to the court that Defendant 2 receive a sentence of five and one-half years. The expected cost of such a plea agreement would be five and one-half years multiplied by 80 percent plus eight years multiplied by 20 percent, or six years. ${ }^{43}$

The rationality of the defendant's ex ante decision does not depend on whether or not the judge actually departs from the recommended sentence. If Defendant 2 is correct in his assumptions about the likelihood of conviction, the probability that the judge will follow the sentence recommendation, and the expected sentence lengths, then it is not irrational for Defendant 2 to plead guilty in exchange for a recommended sentence of five and onehalf years under a type $B$ agreement. This is true even though

\footnotetext{
"The purpose of the sentence bargain is specifically to reassign the risk that the defendant will receive the maximum sentence from a trial conviction. See Scott and Stuntz, 101 Yale L J at 1914 (cited in note 9). It is difficult to collect empirical evidence on downward departures because defendants do not appeal them.

${ }^{42}$ See, for example, Albert W. Alschuler, The Changing Plea Bargaining Debate, 69 Cal L Rev 652, 718-23 (1981) (describing the various reasons given for this practice, such as sparing victims of sensitive crimes the pain of testimony and the concern that defendants in trial often perjure themselves). Under the Federal Sentencing Guidelines, defendants pleading guilty can receive a one or two level reduction in their base offense level for acceptance of responsibility. See United States Sentencing Commission, Guidelines Manual § 3E1.1 at 285 (Nov 1998).

${ }^{43}$ This assumes, perhaps unrealistically, that the probability of judicial departure is independent of the recommended sentence. Here, the acceptable sentence might actually be slightly lower, because the likelihood of departure is not static. The judge is likely to consider a specific sentence, or a range, appropriate; as the prosecutor's sentence recommendation moves away from this point, the judge's likelihood of departure will increase.
} 
Defendant 2 knows that he might not get the recommended sentence and will not be able to withdraw his guilty plea.

This analysis also demonstrates that for almost every type $\mathrm{C}$ plea agreement, there is an equivalent type $B$ agreement for a lower sentence length that is acceptable to the defendant that adjusts for both the risk that the judge will not follow the sentence recommendation and the defendant's attitude toward this risk. For some parties, the premium for the risk of departure may be so large as to render a type $B$ agreement infeasible. ${ }^{44}$ But if a prosecutor offers the defendant a type $\mathrm{C}$ agreement with a higher expected sentence length than the type $B$ agreement offeredpossibly due to each party's attitude toward risk-a rational, risk neutral defendant would choose the type B plea agreement over the type $\mathrm{C}$ plea bargain.

\section{B. The Fairness of Type B Plea Agreements}

1. The different nature of type $B$ and type $C$ agreements.

Type $\mathrm{B}$ and type $\mathrm{C}$ agreements can be structured to create the same expected sentence length for most defendants, but they are qualitatively different. The type $\mathrm{C}$ agreement should be thought of as a contract that contains a condition subsequentjudicial approval after the prosecutor has made her recommendation..$^{45}$ When a court rejects the prosecutor's recommendation, the condition subsequent has not occurred. Accordingly, the defendant is freed from performing and gets to withdraw his guilty plea. The type B agreement contains no such condition. Returning to the two defendants mentioned at the beginning of this Comment best illustrates the difference between the agreements.

Defendant 1 entered into a type $\mathrm{C}$ plea agreement. As a result, when he breached one of the conditions of the agreement, the court either had to accept the agreement-and perhaps require that Defendant 1 cooperate with the prosecution-or reject it, allowing each party to rescind the deal. Type $\mathrm{C}$ agreements are always conditioned on the court's approval, even though the court is not a party to either the negotiation or the agreement. ${ }^{46}$ Rule 11 requires judicial approval as a condition subsequent to type $\mathrm{C}$ agreements because a prosecutor may promise to recommend a binding sentence to the court, but he has no authority to compel the court to accept the recommendation. If the court rejects the

\footnotetext{
"See Part II.C.3.

${ }^{45}$ See United States $v$ Hyde, 520 US 670, 677-78 (1997) (treating judicial approval of a type $\mathrm{C}$ agreement as a condition subsequent).

${ }^{*}$ See FRCrP 11(e)(1).
} 
agreement, the prosecutor automatically is prevented from performing his end of the bargain-that is, he cannot make his recommendation binding. This is analogous to a contractual breach due to impossibility. ${ }^{47}$ Thus, defendants like Defendant 1 must be able to rescind the deal and withdraw their guilty pleas.

Defendant 2, on the other hand, entered into a type B plea agreement with the prosecutor. He agreed to plead guilty and the prosecutor agreed to make a nonbinding recommendation of a five-year sentence to the court. Once Defendant 2 pleaded guilty and the prosecutor made his recommendation to the court, the plea agreement had been carried out-the contract had been performed. The type B agreement has no condition subsequent of judicial approval. Allowing Defendant 2 to withdraw his guilty plea if he does not like the sentence imposed would free him of his obligation to perform. By freeing him of his obligation, withdrawal would allow him to receive the benefit of the bargain, the nonbinding sentence recommendation, as a windfall.

Arguing that Defendant 2 receives a windfall if allowed to withdraw his guilty plea assumes that he receives a benefit from the bargain. One might question the extent to which Defendant 2 benefits from the bargain; after all, a nonbinding recommendation that the judge has ignored seems worthless. ${ }^{48}$ As discussed in Part II.A, however, the type B agreement is not worthless ex ante, or a properly informed, rational defendant would never enter into one. ${ }^{49}$ Often, contracts depend on parties' ex ante determination of the value of a good. As long as the party is not mistaken as to a "basic assumption" of the contract, courts do not permit rescission of the deal, even if the item, ex post, is valueless. ${ }^{50}$

Whether a plea agreement contains a condition subsequent of judicial approval-that is, whether it is a type $B$ or a type $C$ agreement-is a basic assumption of the bargain. Thus, the court must inquire if the defendant is aware that he is agreeing to a

47 See Restatement (Second) of Contracts $§ 261$.

43 Compare United States v Fine, 975 F2d 596, 600 (9th Cir 1992) (referring to the type $B$ and $C$ agreements, as compared to the type $A$ variety as, "the more valuable bargains").

t9 Indeed, when the deal is worthless ex ante, courts are reluctant to find that the plea was made knowingly. See Dillon v United States, 307 F2d 445, 449 (9th Cir 1962) (referring to the prosecutor's bargain as "wholly illusory," when the prosecutor who made the bargain knew that the court would not ask for a sentence recommendation); Maggio, 514 F2d at 91 (stating that a court that never accepts sentence recommendations should inform the defendant of this).

For a discussion on the rationality of choosing the type B agreement, see Part II.A.

${ }^{50}$ See Restatement (Second) of Contracts $\S \S 152-53$ \& comment b (explaining that for a contract to be voided because of the mistake of one party, the mistake must concern a "basic assumption on which the contract was made"). 
type B agreement and warn that he will not be able to rescind the deal, even if the court does not follow the prosecutor's recommendation. ${ }^{51}$ On the other hand, if the court has failed to issue the appropriate warning, and the defendant can show that he was unaware of the nature of the agreement, then he can withdraw his guilty plea. ${ }^{52}$

2. Plea bargaining as removal from the adversarial system.

More than twenty years ago, Congress and the Supreme Court each came to the conclusion that plea bargaining does not violate public policy. ${ }^{53}$ The Court has justified plea bargaining in terms of necessity and efficiency. ${ }^{54}$ However, the fact that the type $\mathrm{B}$ agreement, ex ante, has value does not necessarily mean that its enforcement is fair to defendants. Contracts that violate public policy or are unconscionable may have value but nevertheless are not enforced. This Part explains why sentence agreements, including type B agreements, offer the defendant sufficient benefits to justify permitting him to waive his constitutional rights. ${ }^{55}$

By entering into a plea agreement, a defendant waives several constitutional rights, such as the right to a jury trial, the

${ }^{81}$ See FRCrP 11(e)(2).

"Due process requires guilty pleas to be "voluntary and intelligent." See Brady $v$ United States, 397 US 742, 747 (1970). When the defendant is mistaken as to a "basic assumption" of a plea agreement, enforcing the contract would be unconscionable. See Restatement (Second) of Contracts $\$ 153 \&$ comment b. See also United States $v$ Kennell, 15 F3d 134, 137-38 (9th Cir 1994) (allowing defendant to withdraw guilty plea when trial court did not warn that he could not withdraw after departure from a type B nonbinding recommendation); United States v DeBusk, 976 F2d 300, 306-07 (6th Cir 1992) (same); United States v Ferrara, 954 F2d 103, 108 (2d Cir 1991) (same).

${ }^{3 s}$ See FRCrP 11 and Advisory Committee Notes (1974 Amendment); Brady, 397 US at 753 (refusing to invalidate a plea bargain); Santobello, 404 US at 260 (finding that plea bargaining should be encouraged); Blackledge $v$ Allison, 431 US 63, 71 (1977) ("[T]' guilty plea and the often concomitant plea bargain are important components of this country's criminal justice system.").

${ }^{34}$ See, for example, Brady, 397 US at 751-52 ("Of course, that the prevalence of guilty pleas is explainable does not necessarily validate those pleas ... [b]ut we cannot hold that it is unconstitutional for the State to extend a benefit to a defendant who in turn extends a substantial benefit to the State."); Santobello, 404 US at 260-61 (justifying plea bargaining because it reduces the case load pressure on the courts, avoids pretrial detention, improves chances for rehabilitation, and leads to "prompt" and "final" disposition of cases); Blackledge, 431 US at 71 (noting that the "chief virtues of the plea system" are "speed, economy, and finality"); Scott and Stuntz, 101 Yale L $J$ at 1910 (cited in note 9) (arguing that courts have regulated plea bargaining, "taking for granted the efficiency and decency of the process").

so Compare Scott and Stuntz, 101 Yale L J at 1916-17 (cited in note 9) (asserting that the defendant can waive his rights by plea bargaining because the contract does not create enough negative externalities to outweigh the benefit of the saved costs of a trial). 
privilege against self-incrimination, and the right to confront one's accusers. ${ }^{56}$ Furthermore, the defendant also waives the right to challenge certain antecedent constitutional violations, such as an illegally obtained confession ${ }^{57}$ or an improperly selected grand jury. ${ }^{58}$

Yet the benefit of plea bargaining for the defendant, whether it be for a binding sentence recommendation, a nonbinding sentence recommendation, or even the prosecutor's silence as to a sentence recommendation, is that the defendant is no longer operating within an adversarial system. The prosecutor has become the defendant's advocate, or has at least agreed not to be his opponent. ${ }^{59}$ The constitutional rights waived, such as trial by an impartial jury, confronting one's accusers, and the privilege from self-incrimination, have several purposes, one of which is to protect the defendant from overzealous and improper prosecution; ${ }^{60}$ thus, these rights have less value outside of the adversarial system. ${ }^{61}$ One could argue that plea agreements do not actually

${ }^{56}$ See Santobello, 404 US at 264 (Douglas concurring) ("[A] guilty plea is a serious and sobering occasion inasmuch as it constitutes a waiver of the fundamental rights to a jury trial, to confront one's accusers, to present witnesses in one's defense, to remain silent, and to be convicted by proof beyond a reasonable doubt.") (internal citations ommited).

${ }^{87}$ See McMann v Richardson, 397 US 759 (1970) (finding that a defendant who pleads guilty may not contest an illegally obtained confession).

${ }^{s}$ See Tollett $v$ Henderson, 411 US 258, 266 (1973) (finding that a defendant who pleads guilty may not challenge the selection of the grand jury).

${ }^{59}$ See Scott and Stuntz, 101 Yale $L J$ at 1953-55 (cited in note 9) (considering the prosecutor to be the judge's agent). Compare United States $v$ Crusco, 536 F2d 21, 25-26 (3d Cir 1976) (finding that prosecutor who promised to take no position could not respond to defense attorney's argument at the sentence hearing), and United States $v$ Brown, 500 F2d 375, 377 (4th $\mathrm{Cir}$ 1974) (finding that the government attorney who expressed reservations about the sentence recommendation breached the plea agreement), with Brooks $v$ United States, 708 F2d 1280, 1282 (7th Cir 1983) (prosecutor who promised to make no sentence recommendation could challenge the defendant's motion for a Rule 35 sentence reduction), and United States v Miller, 565 F2d 1273, 1275 (3d Cir 1977) (prosecutor who promised to make no sentence recommendation could note the defendant's lack of cooperation at the sentence hearing without violating the bargain).

${ }^{\infty}$ See Burch $v$ Louisiana, 441 US 130, 135 (1979) ("The purpose of a trial by jury, as noted in Duncan, is to prevent government oppression."); Duncan $v$ Louisiana, 391 US 145,156 (1968) ("Providing an accused with the right to be tried by a jury of his peers gave him an inestimable safeguard against the corrupt or overzealous prosecutor."); Murphy $v$ Waterfront Commission of New York Harbor, 378 US 52, 55 (1964) (noting that one reason for having the privilege against self-incrimination is "our preference for an accusatorial rather than an inquisitorial system of criminal justice; our fear that self-incriminating statements will be elicited by inhumane treatment and abuses").

61 The plea agreement replaces the adversarial system with a weak form of an inquisitorial system. "What makes a system adversarial rather than inquisitorial is ... the presence of a judge who does not (as an inquisitor does) conduct the factual and legal investigation himself, but instead decides on the basis of facts and arguments pro and con adduced by the parties." McNeil $v$ Wisconsin, 501 US 171, 181 n 2 (1991). When the parties have reached an agreement, the judge must make an inquiry to determine if there is a fac- 
change the adversarial interests of the prosecutor-that is, she still desires a conviction with the highest punishment possible for this defendant. However, the prosecutor has another interest that supercedes maximizing the individual defendant's punishment. The prosecutor wants to maximize conviction rates and punishment levels for all defendants. The prosecutor does not evaluate each defendant independently of her resource constraints. And since the prosecutor is a repeat player, she will want to avoid having judges depart from her type $B$ sentence agreements or reject her type $\mathrm{C}$ ones. In order to effectively plea bargain in the long term, the prosecutor wants defendants to be able to rely on courts following her sentence recommendations. So, by agreeing to a sentence recommendation, the prosecutor has committed herself to being an advocate for the deal itself and her own credibility. ${ }^{62}$

The prosecutor's concession in a type B plea agreement to remove herself from the adversarial system and join as an advocate for the deal and, correspondingly, the defendant's interests justifies permitting the defendant to waive his constitutional rights. ${ }^{63}$ This is true even though the defendant still bears a risk that the court will not be persuaded by the prosecutor's recommendation.

\section{The Preferability of Type C Agreements}

Even though 11(e)(1)(B) plea agreements can be rational and are not inherently unfair, prosecutors and defendants sometimes prefer to enter into $11(\mathrm{e})(1)(C)$ plea agreements. Sometimes, as the first example below demonstrates, this choice is motivated by prosecutors' desire to mete out equal punishments to similar defendants. Parties may also prefer the type $\mathrm{C}$ agreement when there is no type $B$ agreement that would be acceptable to them. The second and third examples below illustrate that there may be no acceptable type B agreement when the probability of conviction is low but the punishment would be severe or when the parties are risk averse.

tual basis for the guilty plea. See FRCrP 11(f). Thus, he has become the inquisitor. Of course, the true significance for the defendant of exiting the adversarial system lies in the prosecutor's behavior, not in that of the judge.

${ }^{6}$ See note 59.

क Compare this justification with the standard for permitting waiver of a jury trial (but not other constitutional rights associated with an adversarial trial), which requires "express and intelligent consent," but can be for strategic concerns. Patton $v$ United States, 281 US 276, 312 (1930). See also Wayne R. LaFave and Jerold H. Israel, 2 Criminal Procedure §21.1 at 702-04 (West 1984). 
1. Prosecutors attempting to distribute punishment evenly.

The prosecutor seeks to maximize the number of convictions obtained, while still ensuring that each defendant is punished appropriately. ${ }^{64}$ Thus, if there were ten defendants who had behaved alike, the prosecutor might prefer for each of them to plead guilty and receive a five-year sentence, rather than for nine to plead guilty and receive one-year sentences and the other one to plead guilty and receive a forty-one-year sentence. Although it is plausible that both scenarios achieve the same amount of deterrence, ${ }^{65}$ there is nonetheless an expressive value in achieving equality in punishment. For example, the ABA Standards mandate that "[s]imilarly situated defendants should be afforded equal plea agreement opportunities."66 The scenario depicted above is an exaggerated description of what happens when a prosecutor uses type B plea agreements. Defendants extract a risk premium from prosecutors in type B agreements. Accordingly, prosecutors must agree to recommend a lower sentence under type $\mathrm{B}$ agreements than under type $\mathrm{C}$ ones. For example, as shown earlier, ${ }^{67}$ risk neutral defendants would equate a guaranteed six-year sentence with a recommendation for five and onehalf years, when there is a 20 percent chance that the court will depart upward and impose an eight-year sentence. In exchange for the lower sentence recommendation, the prosecutor receives an eight-year sentence in one out of every five cases. But if the prosecutor truly believes that the defendants to whom she makes the same offer are alike, and should be treated alike, then using the method that guarantees five sentences of six years each is preferable to the method which results in four sentences of five and one-half years and one sentence of eight years. ${ }^{68}$

Furthermore, if the court departs from the recommendation because the prosecutor has made an error in identifying like defendants and has treated one defendant too leniently, then using type $\mathrm{C}$ agreements can result in a higher joint maximum sen-

of See Part I.B.

co Less frequent, more severe punishments may produce less deterrence, because people may be less likely to comply with the law when they perceive that there is rampant law-breaking. See Dan M. Kahan, Social Influence, Social Meaning and Deterrence, 83 Va L Rev 349, 351-52 (1997).

${ }^{66}$ LaFave and Israel, 2 Criminal Procedure $\$ 20.3$ at 623 (cited in note 63), citing 3 ABA Standards for Criminal Justice $§ 14-3.1$ (c) (2d ed 1980). Compare the ABA Standards with United States $v$ Bell, 506 F2d 207, 221-22 (DC Cir 1974) (suggesting that equal protection challenges to plea bargain offers are unreviewable).

${ }^{67}$ See text accompanying note 43 .

6o This is analytically similar to risk aversion, which is discussed in Part II.C.3. But it also includes the normative component of achieving equality. 
tence level. The judge can accept the type $\mathrm{C}$ agreements of the four similar defendants and simply reject that of the fifth. This rejection serves as a signal to both parties that they have miscalculated either the expected cost of going to trial, the cost of pleading guilty, or both. ${ }^{69}$ Rejecting a type $\mathrm{C}$ agreement because it is too lenient may induce the parties to enter into another plea agreement for a higher sentence. Using only type $\mathrm{C}$ agreements prevents the "error costs" of the parties' assessment in one case from being given as a windfall to other defendants.

\section{Defendants facing low likelihood of conviction and severe penalties.}

Defendants facing severe penalties sometimes enter into plea agreements even though their likelihood of conviction is low. ${ }^{70} \mathrm{~A}$ defendant facing a low probability of conviction for a crime with a severe penalty may not find an acceptable sentence range for a type $B$ agreement. Even if there is an acceptable sentence range under a type $\mathrm{C}$ agreement, adding the risk premium for a potential judicial departure from a type $B$ agreement may bring the defendant's acceptable range below the statutory minimum for the crime. There is, therefore, no room for a prosecutor to make a

See note 85 and accompanying text.

${ }^{70}$ See Scott and Stuntz, 101 Yale L J at 1954 (cited in note 9) (noting that the "judge who overturns bargains that seem too favorable to the defense risks punishing precisely those defendants who least deserve it'). Occasionally, these defendants are innocent, which has prompted criticism of plea bargaining as being unduly coercive toward innocent defendants. See Yale Kamisar, Wayne R. LaFave and Jerold H. Israel, Modern Criminal Procedure: Cases, Comments and Questions 1323-24 (West 1994) (arguing that, from the perspective of an innocent defendant, inducements may look like coercion). Compare Scott and Stuntz, 101 Yale L J at 1995-98 (arguing that coercing the innocent to plead guilty imposes unacceptable negative externalities on society), and Schulhofer, $17 \mathrm{~J}$ Legal Stud at 72-73 (cited in note 25) (arguing that plea bargains are often for sentences less than the expected sentence, thus coercing innocent defendants to plead guilty), with Easterbrook, $12 \mathrm{~J}$ Legal Stud at 311-17 (cited in note 9) (arguing that no improper coercion exists because there is no additional penalty for demanding a trial, merely a reward for accepting a plea), and Thomas W. Church, In Defense of "Bargain Justice", 13 L \& Society Rev 509, 513-16 (1979) (arguing that merely offering the opportunity to plea cannot be unfair coercion since innocent defendants can still be found guilty at trial). But while most innocent defendants have low probabilities of conviction, it does not necessarily follow that most defendants with a low likelihood of conviction are innocent. The likelihood of conviction, instead, is affected by the amount of evidence available, the amount of resources the prosecutor and defendant can devote to the case, and whether the jury will sympathize with the defendant. See Alschuler, 69 Cal L Rev at 715-16 (cited in note 42) (arguing that while most commentators, judges, and attorneys estimate that there are few innocent people within the plea bargaining system altogether, this expectation hampers not only those who are innocent, but the ability to estimate how many defendants actually are innocent). Nor is it relevant to the following analysis whether the defendant seeking to minimize punishment is innocent. 
type $B$ deal with the defendant. Note that if the acceptable range for the defendant is low enough, then there might not even be room to make a type $\mathrm{C}$ agreement.

The chances of finding a suitable type $B$ agreement are particularly limited because the probability of judicial departure is likely to be higher in these cases than in those where the defendant is faced with either a higher probability of conviction or a less severe penalty. One reason that judges reject sentence recommendations is that they appear to punish defendants too lightly for the severity of the crime charged. ${ }^{71} \mathrm{~A}$ defendant who pleads guilty to a crime carrying a severe penalty for a comparatively small sentence-one that reflects the low likelihood of conviction-will seem to a judge as having received too lenient a sentence offer. ${ }^{72}$ The risk that the judge will depart from a nonbinding sentence recommendation might be great enough to preclude a type B agreement altogether. ${ }^{73}$

3. Risk averse defendants.

Plea bargaining eliminates the risk of a trial, where the outcome is indeterminate. Risk averse prosecutors and defendants are the most likely parties to seek plea agreements. Take the example of Defendant 1, who entered into a type $\mathrm{C}$ agreement for a sentence of no more than six years. If this agreement reflects the worst possible deal he would accept to forgo a trial, then his expected cost of a trial was six years. Table 1 shows how Defendant 1's attitude toward risk could affect how he determined that the expected cost would be six years.

"Since courts do not have to give reasons for departing from the nonbinding recommendation, United States v Medina-Saldana, 911 F2d 1023, 1024-25 (5th Cir 1990), it is not always clear why courts choose to depart. But cases brought under 11(e)(1)(C) agreements are often rejected because they fail to punish the defendant severely enough for the conduct to which he is pleading guilty. See, for example, United States $v$ Gamboa, 166 F3d 1327, 1330 (11th Cir 1999) (finding that one reason for refusing to accept the plea was that it "did not adequately reflect the seriousness of the offenses"); United States $v$ Bean, 564 F2d 700, 703-04 (5th Cir 1977) ("A decision that a plea bargain will result in the defendant's receiving too light a sentence under the circumstances of the case is a sound reason for a judge's refusing to accept the agreement.").

72 See Scott and Stuntz, 101 Yale L J at 1954 (cited in note 9) ("The current regime basically invites judges to revise bargained-for sentencing recommendations upward when recommended sentences seem unusually low. Yet if the prosecutor and defense counsel agree to recommend an unusually low sentence, that recommendation may reflect the parties' estimation of the probability of conviction.").

${ }^{33}$ Even for risk neutral defendants, since the only way to compensate for a higher probability of judicial departure is an even lower sentence, there may be no equilibrium if the probability of departure rises faster than the length of the agreed-to sentence falls. 
Table 1: Effect of Risk on Acceptable Plea Bargain Range

\begin{tabular}{|l|l|l|l|}
\hline $\begin{array}{c}\text { Defendant's Attitude } \\
\text { Toward Risk }\end{array}$ & $\begin{array}{c}\text { Probability of } \\
\text { Conviction }\end{array}$ & $\begin{array}{l}\text { Expected } \\
\text { Sentence }\end{array}$ & $\begin{array}{c}\text { Maximum Acceptable } \\
\text { Type C Bargain }\end{array}$ \\
\hline IA (Averse) & $60.6 \%$ & 9 years & 6 years \\
\hline IA (Averse) & $66.7 \%$ & 8.18 years & 6 years \\
\hline 1A (Averse) & $66.7 \%$ & 9 years & 6.6 years \\
\hline 1B (Neutral) & $60.6 \%$ & 9 years & 5.45 years \\
\hline 1B (Neutral) & $66.7 \%$ & 8.18 years & 5.45 years \\
\hline IB (Neutral) & $66.7 \%$ & 9 years & 6 years \\
\hline
\end{tabular}

As discussed in Part II.A, type B plea agreements contain a risk premium for all defendants. But this premium is discounted differently, based on the defendant's attitude toward risk. For example, two defendants may wish to enter into type C plea agreements, for a sentence of no more than six years, similar to the one Defendant 1 entered into. Defendant $1 \mathrm{~A}$ is risk averse and Defendant $1 B$ is risk neutral. From Table 1, we know that due to their attitudes toward risk, to get the same acceptable sentencing range, Defendant 1A must have been facing either a lower probability of conviction or a lower expected sentence than Defendant 1B. Converting the type $\mathrm{C}$ agreements to their equivalent type $\mathrm{B}$ agreements results in different acceptable ranges for the defendants. That is, the risk averse Defendant $1 \mathrm{~A}$ will have a lower acceptable sentence range than the risk neutral Defendant 1B. Defendant $1 \mathrm{~B}$ only has to account for judicial departure in determining his acceptable range for a type $B$ agreement. On the other hand, Defendant 1A not only makes this calculation, but also adjusts it for the risk premium paid for this departure.

Courts that refuse to consider type $\mathrm{C}$ plea agreements harm defendants like Defendant 1A. Using type B agreements substantially lowers Defendant 1A's bargaining range, by forcing him to bear a costly risk. This may place his range out of the prosecutor's range altogether, either due to differences in calculating the appropriate range or because the discount from departure places the defendant's acceptable range below a mandatory minimum. Thus, the risk averse defendant (and accordingly, the prosecutor

\footnotetext{
${ }^{7}$ This assumes that the defendant discounts for risk linearly by multiplying the expected sentence by 0.1 to account for the risk premium, and adding it to the acceptable sentence length. In reality, risk aversion often is not linear: the more uncertain an outcome, the greater the premium. Yet since the probabilities of conviction from trial are fairly close in this table, assuming a linear risk aversion discount creates a negligible difference.
} 
negotiating with him) may wish to reach an 11(e)(1)(C) agreement, because there is no acceptable type B agreement to which the two parties could agree. Foreclosing this option will lead the parties to a less preferred solution-a trial.

In summation, both type $B$ and type $C$ plea agreements can be desirable and fair to rational prosecutors and defendants. For some parties, there is little difference between type $\mathrm{B}$ and type $\mathrm{C}$ deals: one has a higher sentence recommendation and the other has a risk of judicial departure. But other parties, as illustrated, may strongly prefer type $\mathrm{C}$ agreements and are disserved by courts that refuse to consider these agreements.

\section{The Role of the Judge IN Plea Bargaining}

Federal judges are not permitted to participate in plea bargain negotiations for several reasons. ${ }^{75}$ First, having a judge negotiate may coerce the defendant to accept a bargain because of the judge's power over the defendant. ${ }^{76} \mathrm{~A}$ suggestion from the judge may create an immediate focal point for the negotiating parties. ${ }^{77}$ A defendant may also feel that he cannot get a fair trial from a judge whose offer he has turned down, because the judge already thinks that he is guilty or that he has wasted the court's time.$^{78}$ In addition, participating in plea bargain negotiations may compromise a judge's ability to evaluate objectively whether the defendant's plea is voluntary and intelligent. ${ }^{79}$

Nonetheless, judges have power over what types of plea agreements are made and how they are executed. The legislative history of Rule 11 shows concern over whether Rule 11 would make plea bargaining mandatory. Congress specifically noted that judges are free to limit to what extent, if any, they would consider plea agreements. ${ }^{80}$ Yet, the options provided in Rule 11 demonstrate congressional deference to the fact that sentencing is traditionally a matter of judicial discretion. Quite possibly,

\footnotetext{
T3 See FRCrP 11(e)(1).

${ }^{i 6}$ See United States $v$ Miles, 10 F3d 1135, 1141 (5th Cir 1993) (vacating a sentence because the court's suggested sentence "dictated the outcome" of the plea agreement).

"See Alschuler, 76 Colum L Rev at 1103-08 (cited in note 35). For a general discussion of "focal points" in bargaining models, see Thomas Schelling, The Strategy of Conflict 68-74 (Oxford 1960).

${ }^{78}$ See United States $v$ Werker, 535 F2d 198, 202 (2d Cir 1976) (arguing that the defendant may be, or may believe that he is, prejudiced if he does not accept the judge's suggested plea).

${ }^{79}$ See Alschuler, 76 Colum L Rev at 1114-16 (cited in note 35) (noting that busy judges often pay little attention to cases involving guilty pleas).

See Federal Rules of Criminal Procedure Amendments Act of 1975, HR Rep No 90247, 94th Cong, 1st Sess 6, reprinted in 1975 USCCAN 674, 678-79.
} 
Rule 11 extended the judicial power to the area of prosecutorial charging discretion, by permitting judges to reject agreements that indirectly limit sentencing power through charge dismissals. ${ }^{81}$ Furthermore, the enactment of the Federal Sentencing Guidelines has lessened the need for strict judicial control of plea agreements. ${ }^{82}$

While some courts have perceived the Rule 11 plea bargaining options as a threat to their discretionary power and to the criminal justice system as a whole,$^{83}$ courts can use the powers granted by the Rule to encourage prosecutors and defendants to enter into more precise, informed, and appropriate plea agreements. This can best be done by using a combination of all three agreement types, and particularly by encouraging type $\mathrm{C}$ agreements over type $B$ agreements.

There are two reasons for this. First, the court's decision to reject a type $C$ agreement can serve as a signal to the parties that either one or both parties has made an error in calculating the expected sentence from trial. ${ }^{84}$ If Type $\mathrm{B}$ agreements are used, every case has a risk premium due to the potential for "error." Type $\mathrm{C}$ agreements, on the other hand, allow the court to identify these mistakes without affecting the disposition of other cases. That is, the court gets to accept or reject the type $\mathrm{C}$ agreements rather than extracting a risk premium that serves to lower most defendants' sentences at the expense of the few inappropriate type $B$ agreements. Courts are often in the best position to know the information relating to potential errors, such as what sentencing range is permissible under the guidelines, but cannot share information with the parties for fear of improper "participation." ${ }^{85}$

" Compare United States v Castra-Cervantes, 927 F2d 1079, 1082 (9th Cir 1991) (holding that a court should reject a type A agreement if it is too lenient, and should consider dismissed charges in calculating the appropriate sentence), with United States $v$ Ammidown, 497 F2d 615, 623 (DC Cir 1972) (holding that judges may reject a type A agreement only after a determination that the prosecutor "abused his discretion").

${ }^{22}$ See United States $v$ Pimentel, 932 F2d 1029, 1033 (2d Cir 1991) ("The notion that judges might frown on sentence bargain agreements evolved at a time when courts enjoyed a virtual monopoly over sentencing decisions.").

See note 9 .

* For an example of parties that chose to renegotiate after the court rejected a type C agreement because it was too lenient, see United States $v$ LeMay, 952 F2d 995, 997 (8th Cir 1991). In United State v Gordon, 61 F3d 263, 266 (4th Cir 1995), the defendant chose to resubmit her guilty plea as part of a type B agreement, after the court rejected a type $C$ agreement that failed to include the required sentence enhancements. When courts modify type B recommendations, they signal information about appropriate sentencing to future parties; but in type $\mathrm{C}$ cases, providing the information actually affords the affected parties the opportunity to use this information to their benefit.

${ }^{*}$ See, for example, United States v Sandles, 80 F3d 1145, 1148 (7th Cir 1996) (finding 
Using type $\mathrm{C}$ agreement rejections as a signal for the parties is not impermissible participation; ${ }^{86}$ however, courts rejecting type $\mathrm{C}$ agreements may not tell the parties what agreement they would accept. ${ }^{87}$ The purpose for this distinction parallels the justifications for disallowing judicial participation in negotiations. Not allowing judges to reveal what bargain they would accept prevents unintentional coercion because of the judge's presence. The judge may not offer a focal point solution to the parties, but may convey why the first agreement was inadequate. The defendant still may fear that the judge has decided that he is guilty, but Rule 11(e)(6) prevents the judge from using the defendant's previous attempt to enter a guilty plea to implicate him. ${ }^{88}$ Lastly, the judge will not be invested in a subsequent plea agreement, so his objectivity should not be compromised in evaluating whether it was voluntarily and knowingly made.

On the other hand, an $11(\mathrm{e})(1)(\mathrm{C})$ rejection may signal that the court has made an error in calculating the expected costs of trial. For example, the judge may overestimate the resources available to the prosecutor to try the case. Still, the prosecutor and defendant can choose whether to proceed and attempt to reach a meeting of the minds acceptable to the judge. While there is little recourse for the party that is harmed by the court's error, at least the party can choose its next course of action. A judge's mistake in evaluating a type B agreement is essentially unreviewable. ${ }^{89}$

that disagreement over effect of defendant's stipulation to being a "career offender" is akin to a mutual misunderstanding and "[w] here there is a mutual misunderstanding as to the material terms of a contract, the appropriate remedy is rescission, not unilateral modification"); United States v Husband, 748 F Supp 476, 480 (E D Tex 1989) (rejecting agreement because the maximum sentence that could be imposed under the guidelines was far less than the plea indicated on its face). Compare the treatment of a type $A$ agreement in United States $v$ Bos, 917 F2d 1178, 1182 (9th Cir 1990) ("[M] utual mistake of law [as to the guidelines] is not grounds for invalidating [a] plea bargain.").

Note that neither the prosecutor nor the court accepting a guilty plea is required to inform the defendant of the applicable guidelines range. See United States $v$ Rutter, 897 F2d 1558, 1564 (10th Cir 1990); Pimentel, 932 F2d at 1034 (suggesting that the number of appeals claiming "unfair surprise" would be reduced if prosecutors would inform defendants of the likely range of sentences that the guidelines authorize).

${ }^{86}$ See LeMay, 952 F2d at 997 (rejecting defendant's first plea agreement because it called for a lighter sentence than that imposed on less culpable defendants).

${ }^{87}$ See Miles, $10 \mathrm{~F} 3 \mathrm{~d}$ at 1139 (holding that the district court committed harmful error by participating in plea bargain negotiations).

See FRCrP 11(e)(6).

See Medina-Saldana, 911 F2d at 1024-25 (holding that a court does not have to give a reason for departing from a nonbinding sentence recommendation). Compare United States $v$ Moore, 637 F2d 1194, 1196 (8th Cir 1981) (holding that the court does not have to give a reason for rejecting a type $\mathrm{C}$ agreement), with United States $v$ Moore, 916 F2d 1131, 1135-36 (6th Cir 1990) (remanding to allow court to explain its rejection of the type C 
The second reason judges should encourage parties to use type $\mathrm{C}$ agreements is that this procedure preserves institutional capital ${ }^{90}$ through respect for the parties' freedom to contract. The rejection affords the parties another opportunity to decide the disposition of the case. Departing from the sentence recommended under a type B agreement, on the other hand, may be a more intrusive form of judicial review of the contract. When courts exercise the power granted to them either by modifying the nonbinding sentence recommendations or by rejecting type $\mathrm{C}$ binding recommendations, that power carries the costs of making the judicial system seem less legitimate ${ }^{11}$ and harming prosecutors' ability to make credible promises to defendants. ${ }^{92}$ But when the parties prefer a type $\mathrm{C}$ agreement over a type $\mathrm{B}$ one, yet reach a type B bargain due to outside factors (like some courts' treatment of type $\mathrm{C}$ bargains), the modification of the agreed upon sentence recommendation is less legitimate than the rejection of the deal in a type $\mathrm{C}$ form would have been. This is because the parties did not receive their ideal bargain.

\section{CONCLUSION}

Rule 11 of the Federal Rules of Criminal Procedure provides two different options for parties wishing to reach plea agreements for the length of the sentence-the type $B$ nonbinding and the type $\mathrm{C}$ binding sentence recommendations. These choices properly recognize that parties in different situations may prefer judicial flexibility in modifying an "inappropriate" sentence recommendation or may wish to restrict it. Although some commentators have proposed making all sentence recommendations binding, ${ }^{93}$ there is no inherent flaw in type $\mathrm{B}$ agreements, even if they can disappoint defendants who do not receive the sentences for which they had hoped. When courts limit the use of type $\mathrm{C}$

agreement), and United States $v$ Delegal, 678 F2d 47, 50 (7th Cir 1982) ("[A] defendant is entitled to plead guilty unless the district court can articulate a sound reason for rejecting the plea.").

${ }^{\infty}$ The idea that courts have an exhaustible supply of capital that should be preserved for defending individual rights when they are attacked by hostile majorities appears in Jesse H. Choper, Judicial Review and the National Political Project: A Functional Reconsideration of the Role of the Supreme Court (Chicago 1980).

${ }^{91}$ See Kamisar, LaFave and Israel, Modern Criminal Procedure at $1310 \mathrm{n}$ p (cited in note 70), citing the New York State Special Commission on Attica, Attica 30-31 (1972) (describing prisoner attitudes toward plea bargaining as bitter, because many believed that "the judge did not keep the state's promise of a sentence which had induced them to enter guilty pleas").

${ }^{92}$ See note 36 and accompanying text.

${ }^{33}$ See Scott and Stuntz, 101 Yale L J at 1953-57 (cited in note 9). 
agreements, however, it may force risk averse parties, defendants faced with a low probability of conviction for severe crimes, and prosecutors attempting to equalize the distribution of punishment, to choose less desired options. Also, using only type B agreements may extract a greater cost on the judiciary, because it requires judges to modify contracts, rather than reject them, which less legitimately reflects the parties' interests. Furthermore, the type $\mathrm{C}$ agreement has the added benefit of allowing the judge to signal to the parties in a manner that allows them to use this information, without illegally participating in negotiations, that the parties have made mistakes in their underlying expectations. Since the acceptance of plea agreements is, in part, tied to their rationality, providing this information helps the parties agree to more efficient deals. Because of this benefit, as well as the harms of foreclosing type $\mathrm{C}$ agreements, courts should consider type $\mathrm{C}$ plea agreements and encourage parties to enter into them. 